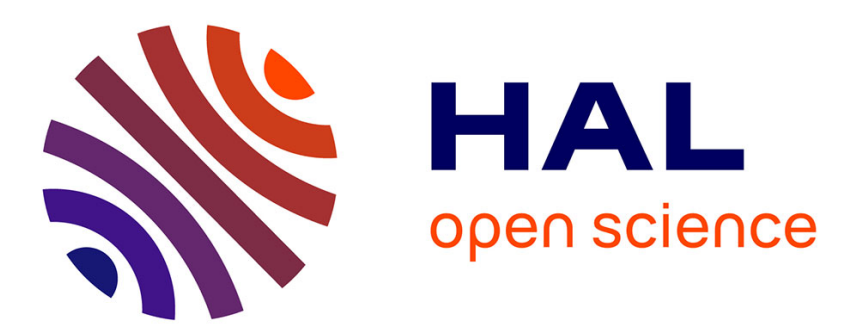

\title{
An innovative efficient oxygen electrode for SOFC: Pr6O11 infiltrated into Gd-doped ceria backbone
}

Clément Nicollet, Aurélien Flura, Vaibhav Vibhu, Aline Rougier, Jean-Marc. Bassat, Jean-Claude Grenier

\section{- To cite this version:}

Clément Nicollet, Aurélien Flura, Vaibhav Vibhu, Aline Rougier, Jean-Marc. Bassat, et al.. An innovative efficient oxygen electrode for SOFC: Pr6O11 infiltrated into Gd-doped ceria backbone. International Journal of Hydrogen Energy, 2016, 41 (34), pp.15538-15544. 10.1016/j.ijhydene.2016.04.024 . hal-01360432

\section{HAL Id: hal-01360432 \\ https://hal.science/hal-01360432}

Submitted on 19 Jan 2021

HAL is a multi-disciplinary open access archive for the deposit and dissemination of scientific research documents, whether they are published or not. The documents may come from teaching and research institutions in France or abroad, or from public or private research centers.
L'archive ouverte pluridisciplinaire HAL, est destinée au dépôt et à la diffusion de documents scientifiques de niveau recherche, publiés ou non, émanant des établissements d'enseignement et de recherche français ou étrangers, des laboratoires publics ou privés. 


\title{
An innovative efficient oxygen electrode for SOFC: $\mathrm{Pr}_{6} \mathrm{O}_{11}$ infiltrated into Gd-doped ceria backbone
}

\author{
Clément Nicollet, Aurélien Flura, Vaibhav Vibhu, Aline Rougier, Jean-Marc Bassat, Jean-Claude \\ Grenier
}

CNRS, Université de Bordeaux, ICMCB, 87 Av. Dr Schweitzer, Pessac-Cedex, F-33608, France

\begin{abstract}
The praseodymium oxide, $\mathrm{Pr}_{6} \mathrm{O}_{11}$, is regarded as a potential electrocatalyst for the oxygen reduction reaction. Its mixed conductivity properties are characterized. At $600{ }^{\circ} \mathrm{C}$ the oxygen diffusion coefficient value is as high as $3.4 \times 10^{-8} \mathrm{~cm}^{2} \mathrm{~s}^{-1}$, and that of the surface exchange coefficient is $5.4 \times 10^{-7} \mathrm{~cm} \mathrm{~s}^{-1}$, which supposes excellent electrocatalytic properties. The measured electronic conductivity is high enough for using this material as a SOFC cathode. Herein, praseodymium nitrate is infiltrated into Gd doped ceria (GDC) backbone and fired at $600{ }^{\circ} \mathrm{C}$ to form a composite oxygen electrode $\operatorname{Pr}_{6} \mathrm{O}_{11} /$ GDC. Electrochemical measurements show very low polarization resistance, $R \mathrm{p}=0.028 \Omega \mathrm{cm}^{2}$ at $600{ }^{\circ} \mathrm{C}$. A single cell made of a commercial Ni-YSZ/YSZ half cell and of the infiltrated cathode is able to deliver a maximum power density of $825 \mathrm{~mW} \mathrm{~cm}^{-2}$ at $600{ }^{\circ} \mathrm{C}$. Ageing of this cell for $840 \mathrm{~h}$, at $600{ }^{\circ} \mathrm{C}$ and $0.5 \mathrm{~A} \mathrm{~cm}^{-2}$, shows a degradation rate lower than $1 \%$.
\end{abstract}

Keywords: Solid oxide fuel cells / Composite cathodes / Praseodymium oxide / Infiltration process / Ageing SOFC test.

\section{Introduction}

Mixed electronic and ionic conductors are good candidates for improving the oxygen reduction reaction (ORR) at the cathode side in solid oxide fuel cells (SOFC) [1], [2]. Most of them contain alkaline-earth elements such as strontium or barium, cations that easily diffuse, segregate or react with other cells components as well as with $\mathrm{CO}_{2}$. In a recent review, Chen et al. [3] claimed that searching for alkaline earth-free electrode materials is highly desirable with respect to these issues.

Among novel cathode materials, those containing Pr cations show good electrocatalytic properties as for instance, the Ruddlesden-Popper (RP) phase $\operatorname{Pr}_{2} \mathrm{NiO}_{4+}$. It exhibits high oxygen diffusion and oxygen surface exchange coefficients, as well as a good electronic conductivity [4]. However, it has recently been evidenced that this compound decomposes when held at intermediate temperatures such as those targeted by the SOFC application $\left(600-800{ }^{\circ} \mathrm{C}\right)$, forming the $\mathrm{n}=3 \mathrm{RP}$ term, $\mathrm{Pr}_{4} \mathrm{Ni}_{3} \mathrm{O}_{10+} \delta$, the perovskite $\mathrm{PrNiO}_{3-\delta}$, as well as the simple oxide $\mathrm{Pr}_{6} \mathrm{O}_{11}$ [5], [6]. While for most materials, such a decomposition is detrimental with regard to the electrocatalytic efficiency, for $\operatorname{Pr}_{2} \mathrm{NiO}_{4+\delta}$, it was reported that the polarization resistance of the electrode at $i_{d c}=0$ remains quite stable with time [6]. More recently, we studied a cathode made of Gd (gadolinium) doped ceria (GDC) infiltrated with $\operatorname{Pr}_{2} \mathrm{NiO}_{4+\delta}$ that showed polarization resistances as low as $0.075 \Omega \mathrm{cm}^{2}$ at $600{ }^{\circ} \mathrm{C}$, while the presence of $\operatorname{Pr}_{6} \mathrm{O}_{11}$ as secondary phase was also noticed [7].

It is also interesting to note that few recent studies have reported an improvement of the electrochemical performance when using $\operatorname{Pr}_{6} \mathrm{O}_{11}$ as additive in composite electrodes made for instance of LNF ( $\left.\mathrm{LaNi}_{0.6} \mathrm{Fe}_{0.4} \mathrm{O}_{3-\delta}\right)$ or LSM $\left(\mathrm{La}_{0.8} \mathrm{Sr}_{0.2} \mathrm{MnO}_{3}\right)-\mathrm{GDC}$, either mixed or infiltrated with $\mathrm{Pr}_{6} \mathrm{O}_{11}$ [8], [9], [10], [11]. Then, with respect to these features, it becomes mandatory to examine the exact role played by this simple oxide from an electrochemical viewpoint. 
In the praseodymium - oxygen phase diagram, six $\mathrm{PrO}_{\mathrm{x}}$ phases with various oxygen stoichiometries, belonging to the series $\operatorname{Pr}_{n} \mathrm{O}_{2 n-2}(\mathrm{n}=4,7,9$ 10, 11, 12, $\infty)$, have been evidenced [12]. Except $\mathrm{PrO}_{2}$, all exhibit two oxidation states $(3+$ and $4+)$; the stable oxide at room temperature is $\operatorname{Pr}_{6} \mathrm{O}_{11}(\mathrm{n}=12)$ and only a few studies have been concerned with its properties [12], [13], [14].

In this work, we aim to study $\operatorname{Pr}_{6} \mathrm{O}_{11}$ as a potential electrocatalyst of the oxygen reduction reaction (ORR) for a SOFC cathode. Due to phase transitions upon increasing temperature, this oxide undergoes volume changes that may induce cracks and delamination in screen-printed electrodes during sintering. Herein, $\mathrm{Pr}_{6} \mathrm{O}_{11}$ will be infiltrated into GDC backbones to form composite electrodes, as the infiltration technique is known to be able to solve such issues [15]. From an application viewpoint, this process is simple and low cost, and has been reported for a large variety of materials to yield highly efficient electrodes [15], [16], [17].

\section{Experimental}

\section{Sample preparation}

The praseodymium oxide, $\operatorname{Pr}_{6} \mathrm{O}_{11}$, was prepared by a glycine - nitrate process (GNP), starting from a commercial praseodymium nitrate (Aldrich), which led to an oxide powder of fine granulometry $(<0.2 \mu \mathrm{m})$ that favors the densification. The GNP powder was uniaxially pressed, then sintered at $1350{ }^{\circ} \mathrm{C}$ for $10 \mathrm{~h}$, in oxygen, with heating and cooling ramps of $3{ }^{\circ} \mathrm{C} \mathrm{min}{ }^{-1}$. This protocol significantly reduced the formation of cracks, leading to $95 \%$ dense pellets with a diameter $\varnothing=5.5 \mathrm{~mm}$. The density of the pellets was determined by the Archimede's method.

\section{Electrical and oxygen diffusivity measurements}

The electrical conductivity was measured on dense pellets by the four probe technique, in air, between room temperature and $800{ }^{\circ} \mathrm{C}$. The oxygen diffusivity was determined using the isotopic exchange depth profiling (IEDP) technique as previously reported [4]. Dense pellets were first abraded with silicon carbide papers of successive grades and then polished with an alumina paste $(0.3 \mathrm{Am})$. Then, they equilibrated at $600{ }^{\circ} \mathrm{C}$ in a ${ }^{16} \mathrm{O}$ pressure of $210 \mathrm{mbar}$, and then quenched down to room temperature. The ${ }^{16} \mathrm{O}$ was pumped out of the setup and replaced by the ${ }^{18} \mathrm{O}$ diffusion tracer at the same pressure. The sample was put again at the same temperature for a controlled time to partly exchange ${ }^{16} \mathrm{O}$ with ${ }^{18} \mathrm{O}$. Finally, the diffusion profile was recorded with a Cameca IMS $6 \mathrm{~F}$ secondary ion mass spectrometer (SIMS) with a $\mathrm{Cs}^{+}$source.

\section{Electrochemical measurements}

The electrochemical characterizations were carried out on symmetrical cells. They were prepared starting from commercial membranes (kindly provided by ECN (The Netherlands)) made of 3\% yttria stabilized zirconia (TZ3Y) of around $100 \mu \mathrm{m}$ thickness and $25 \mathrm{~mm}$ diameter, on which a porous backbone of Gd-doped ceria (GDC) (diameter $15 \mathrm{~mm}$ ) was prepared as follows: a commercial GDC powder (Rhodia) was attrited with zirconia balls in ethanol, for $3 \mathrm{~h}$, then mixed with a pore forming agent (carbon super p), terpineol, and ethyl cellulose to form an ink which was screen printed on both sides of the TZ3Y membrane. A $\mathrm{LaNi}_{0.6} \mathrm{Fe}_{0.4} \mathrm{O}_{3-\delta}$ (LNF) collecting layer was also screen printed on the backbone prior to sintering. The assembly was heated at $1150{ }^{\circ} \mathrm{C}$ for $1 \mathrm{~h}$ to provide a good mechanical resistance of the backbone. Then, both Gd-doped ceria backbone ( 7 or $14 \mu \mathrm{m}$ thick) and LNF $(10 \mu \mathrm{m}$ thick) were infiltrated with solutions of Pr nitrate $(\approx 2 \mathrm{M})$. An infiltration step consisted in: 
i) applying a drop of solution on the backbone, ii) putting the sample under primary vacuum for $2 \mathrm{~min}$, iii) wiping the solution excess with an absorbing paper, iv) firing the infiltrate at $450{ }^{\circ} \mathrm{C}$ for $20 \mathrm{~min}$. This infiltration step was repeated till the infiltrate amount reaches $30 \mathrm{wt}$. $\%$ of the backbone (3-4 times). The annealing step was operated in the impedance measurement setup at low temperature, i.e. $600{ }^{\circ} \mathrm{C}$ for $2 \mathrm{~h}$.

The symmetrical cells were placed between two gold grids supported by channeled ceramics that enhance the gas diffusion toward active sites of the electrodes. Impedance spectroscopy diagrams were recorded every $50{ }^{\circ} \mathrm{C}$ between $600{ }^{\circ} \mathrm{C}$ and $400{ }^{\circ} \mathrm{C}$ at $i_{\mathrm{dc}}=0$ with a Solartron Modulab frequency response analyzer. The frequency range was $1 \mathrm{MHz}-10 \mathrm{mHz}$ for $400{ }^{\circ} \mathrm{C}$ and $450{ }^{\circ} \mathrm{C}$, above $(500$ $600{ }^{\circ} \mathrm{C}$ ) the low frequency limit was $100 \mathrm{mHz}$. The Kramer-Kronig test was carried out to validate the good quality of the measurements and to withdrawn the part of the diagrams (usually at high frequency) where the KK test was not satisfactory. The AC amplitude was $50 \mathrm{mV}$. The impedance diagrams were fitted using in-house software (CANELEIS). Single cells were made starting from commercial Ni-YSZ/YSZ half-cells (diameter $\varnothing=50 \mathrm{~mm}$ ); the cathode was prepared using the same protocol as for symmetrical cells, for both the backbone and the infiltration process (diameter $\varnothing=16 \mathrm{~mm}$ ). Then, they were mounted in a measurement setup for single cells with Ni foam as anode current collector, gold grid as cathode current collector, and with air and hydrogen gas supply at each side of the cell. The setup was not sealed for gas tightness, the excess of gas being burnt at the edges.

\section{Microstructure characterization}

Images of the microstructure were recorded with a field emission scanning electron microscope Jeol JSM $6700 \mathrm{~F}$ at an acceleration voltage of $1 \mathrm{kV}$. Prior to analyses the samples were covered with a thin sputtered palladium layer to avoid electron charging. Then, the samples were fractured and images were taken on the cross section.

\section{Results and discussions}

\section{Transport properties}

In a first step, electrical conductivity measurements were carried out on $\operatorname{Pr}_{6} \mathrm{O}_{11}$ dense pellets from room temperature up to $800^{\circ} \mathrm{C}$. Fig. 1 shows the thermal variation of the electrical conductivity. Even though $\operatorname{Pr}_{6} \mathrm{O}_{11}$ has praseodymium with a mixed valence $3+/ 4+$, the electrical conductivity is rather low $\left(1.3 \mathrm{~S} \mathrm{~cm}^{-1}\right.$ at $600{ }^{\circ} \mathrm{C}$ and $3.7 \mathrm{~S} \mathrm{~cm}^{-1}$ at $\left.800{ }^{\circ} \mathrm{C}\right)$. The conduction behavior is of semi-conductor type over the whole temperature range and is in agreement with a study previously reported by Thangadurai et al. [13]. Rao et al. [18] suggested that the band width in rare earth oxides is narrow, and that the electronic conduction mechanism in $\operatorname{Pr}_{6} \mathrm{O}_{11}$ is a small polaron-type. Additionally, one can note that the activation energy decreases around $470{ }^{\circ} \mathrm{C}$, which could be related to the order/disorder transition of oxygen vacancies reported by Hyde et al. [12]. 


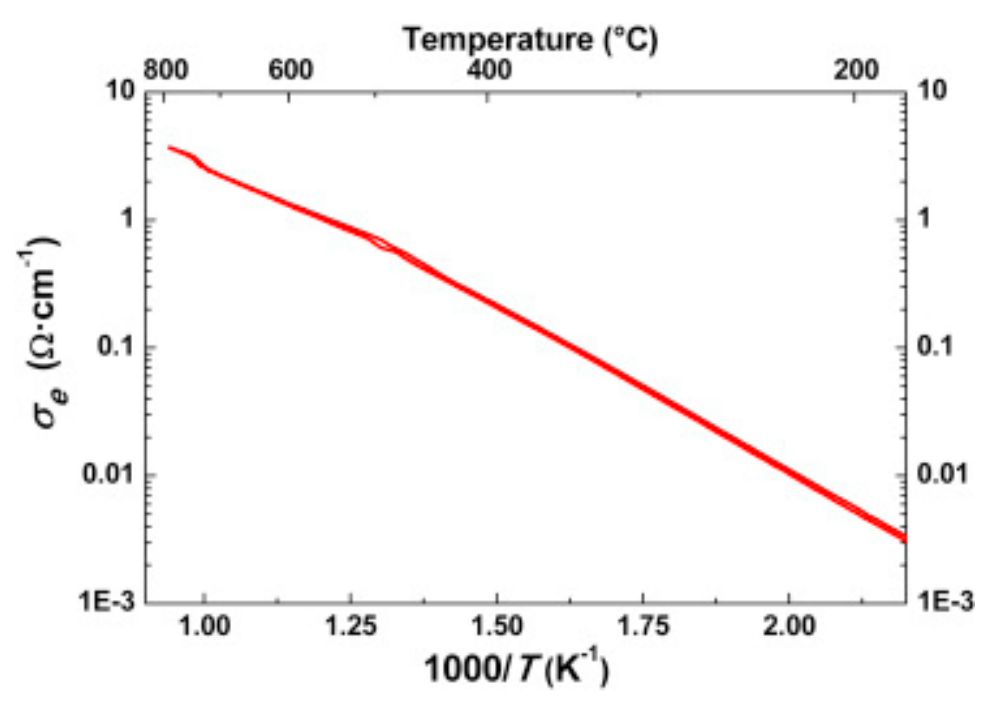

Fig. 1. Thermal variation of the electrical conductivity of $\mathrm{Pr}_{6} \mathrm{O}_{11}$ as a function of temperature.

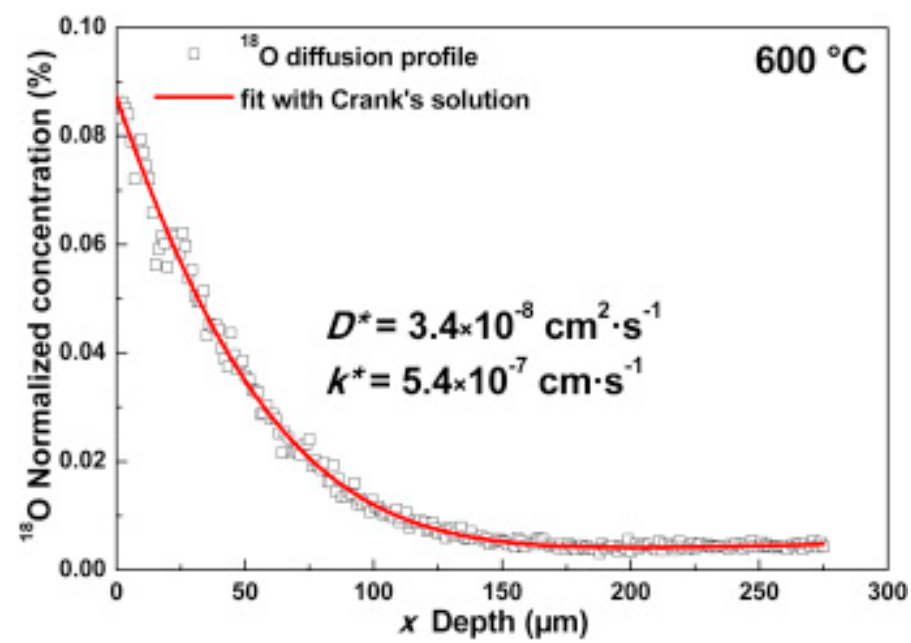

Fig. 2. Normalized ${ }^{18} \mathrm{O}$ diffusion profile recorded for $\mathrm{Pr}_{6} \mathrm{O}_{11}$ after ${ }^{16} \mathrm{O} /{ }^{18} \mathrm{O}$ exchange at $600{ }^{\circ} \mathrm{C}$ for $13 \min 30 \mathrm{~s}$.

The oxygen diffusion and surface exchange coefficients were then determined after ${ }^{16} \mathrm{O} /{ }^{18} \mathrm{O}$ exchange carried out at $600{ }^{\circ} \mathrm{C}$, for $13 \mathrm{~min} 30 \mathrm{~s}$ on a dense $\operatorname{Pr}_{6} \mathrm{O}_{11}$ pellet. The ${ }^{18} \mathrm{O}$ diffusion profile measured by Secondary Ion Mass Spectroscopy is shown in Fig. 2. The ${ }^{18} \mathrm{O}$ diffused on roughly $200 \mu \mathrm{m}$ into the pellet, and the profile can be fitted using the Crank's solution of the Fick second law for diffusion in semi-infinite media [19] (equation (1)):

$$
\begin{aligned}
C 1(x)= & \operatorname{erfc}\left(\frac{x}{2 \sqrt{D^{*} t}}\right)-\exp \left(\frac{k^{*}}{D^{*}} x+\left(\frac{k^{*}}{D^{*}}\right)^{2} t\right) \times \operatorname{erfc}\left\{\left(\frac{x}{2 \sqrt{D^{*} t}}\right)\right. \\
& \left.+\left(\frac{k^{*}}{D^{*}} \sqrt{D^{*} t}\right)\right\}+A \exp \left(-Z x^{6 / 5}\right)
\end{aligned}
$$

where $\mathrm{C} 1(\mathrm{x})$ is the $\mathrm{O}^{18}$ concentration as a function of $\mathrm{x}$, the depth, $D^{*}$ is the oxygen diffusion coefficient, $k^{*}$ the surface exchange coefficient, is the exchange time, and $\mathrm{A}$ and $\mathrm{Z}$ are parameters 
related to the grain boundary diffusion. The fit gives the following values: $D^{*}=3.4 \times 10^{-8} \pm$ $0.1 \times 10^{-8} \mathrm{~cm}^{2} \mathrm{~s}^{-1}$ and $k^{*}=5.4 \times 10^{-7} \pm 0.1 \times 10^{-7} \mathrm{~cm} \mathrm{~s}^{-1}$. It is the first time that such an experiment is carried out on $\operatorname{Pr}_{6} \mathrm{O}_{11}$ and $D^{*}$ and $k^{*}$ values are of the same order of magnitude as those previously reported for $\operatorname{Pr}_{2} \mathrm{NiO}_{4+\delta}$ that is currently one of the best SOFC cathode materials [4], [20].

$\operatorname{Pr}_{6} \mathrm{O}_{11}$ has a cubic fluorite-type structure, typical of that of well-known good ionic conductors such as yttria doped zirconia (YSZ) or GDC. The unit formula at room temperature, $\mathrm{PrO}_{1.83}$, means that the oxygen vacancy content is 0.17 . This oxide loses oxygen as the temperature increases [12], which creates additional vacancies and induces oxygen mobility, especially in the disordered state $\left(\mathrm{T}>470{ }^{\circ} \mathrm{C}\right)$. In addition, $\operatorname{Pr}_{6} \mathrm{O}_{11}$ oxide exhibits a high surface exchange coefficient, likely resulting from the ease of praseodymium to change its valence state between $3+$ and $4+$. Its poor electronic conductivity (nevertheless two orders of magnitude larger than the ionic conductivity of the GDC backbone) seems not to be a limiting factor for the oxygen reduction reaction.

\section{Electrochemical measurements on symmetrical cells}

Next step was to characterize the infiltrated electrodes using electrochemical impedance spectroscopy.

Fig. 3 shows SEM images of the GDC backbone before and after infiltration with $\operatorname{Pr}_{6} \mathrm{O}_{11}$ annealed at $600{ }^{\circ} \mathrm{C}$. Such a low annealing temperature results in very fine $\operatorname{Pr}_{6} \mathrm{O}_{11}$ nanoparticles dispersed on the surface of GDC grains.

The electrochemical impedance of infiltrated electrodes was first measured in a symmetrical cell configuration on three infiltrated samples as follows: in earlier works [7], [21], the infiltration of $\mathrm{Pr}_{2} \mathrm{NiO}_{4+\delta}$ into $\mathrm{La}_{0.9} \mathrm{Sr}_{0.1} \mathrm{Ga}_{0.8} \mathrm{Mg}_{0.2} \mathrm{O}_{3-\delta}$ or GDC led to very efficient electrodes, even though the presence of $\mathrm{Pr}_{6} \mathrm{O}_{11}$ and $\mathrm{NiO}$ additional phases was suspected to play a role in the electrochemical behavior of the electrode [7]. To clarify this role, it was therefore interesting to compare the former results of $\operatorname{Pr}_{2} \mathrm{NiO}_{4+\delta}$ infiltrated into GDC backbone with a $\mathrm{Pr}_{6} \mathrm{O}_{11}$ infiltrated electrode as well as with one infiltrated only with $\mathrm{NiO}$.

The thermal variation of the polarization resistances of these three infiltrated samples is reported in Fig. 4. When the electrode is only infiltrated with $\mathrm{NiO}$ the polarization resistance is high, i.e. $1.4 \Omega \mathrm{cm}^{2}$ at $600{ }^{\circ} \mathrm{C}$. The cell infiltrated only with a praseodymium solution, however, yields an extraordinary low polarization resistance, even lower than the results previously obtained for the $\operatorname{Pr}_{2} \mathrm{NiO}_{4+\delta}$ infiltrated electrode, reaching $0.028 \Omega \mathrm{cm}^{2}$ at $600{ }^{\circ} \mathrm{C}, 0.14 \Omega \mathrm{cm}^{2}$ at $500{ }^{\circ} \mathrm{C}$, and $3.5 \Omega \mathrm{cm}^{2}$ at $400{ }^{\circ} \mathrm{C}$. It is worth noting that it is the first time an electrode material without $3 \mathrm{~d}$ cations is considered. Indeed, up to now, materials for oxygen electrodes showing good electrocatalytic properties are based on mixed valences of $3 \mathrm{~d}$ cations such as $\mathrm{Mn}, \mathrm{Fe}$ or Co [2]. Here, it is assumed that the mixed valence of the praseodymium cations in $\operatorname{Pr}_{6} \mathrm{O}_{11}$ is likely to be responsible for such a high efficiency toward the oxygen reduction reaction. Previous works [8], [9], [10] reported the beneficial effect of $\operatorname{Pr}_{6} \mathrm{O}_{11}$ as additive in oxygen electrode but all these results did not lead to polarization resistances as low as those measured here. 


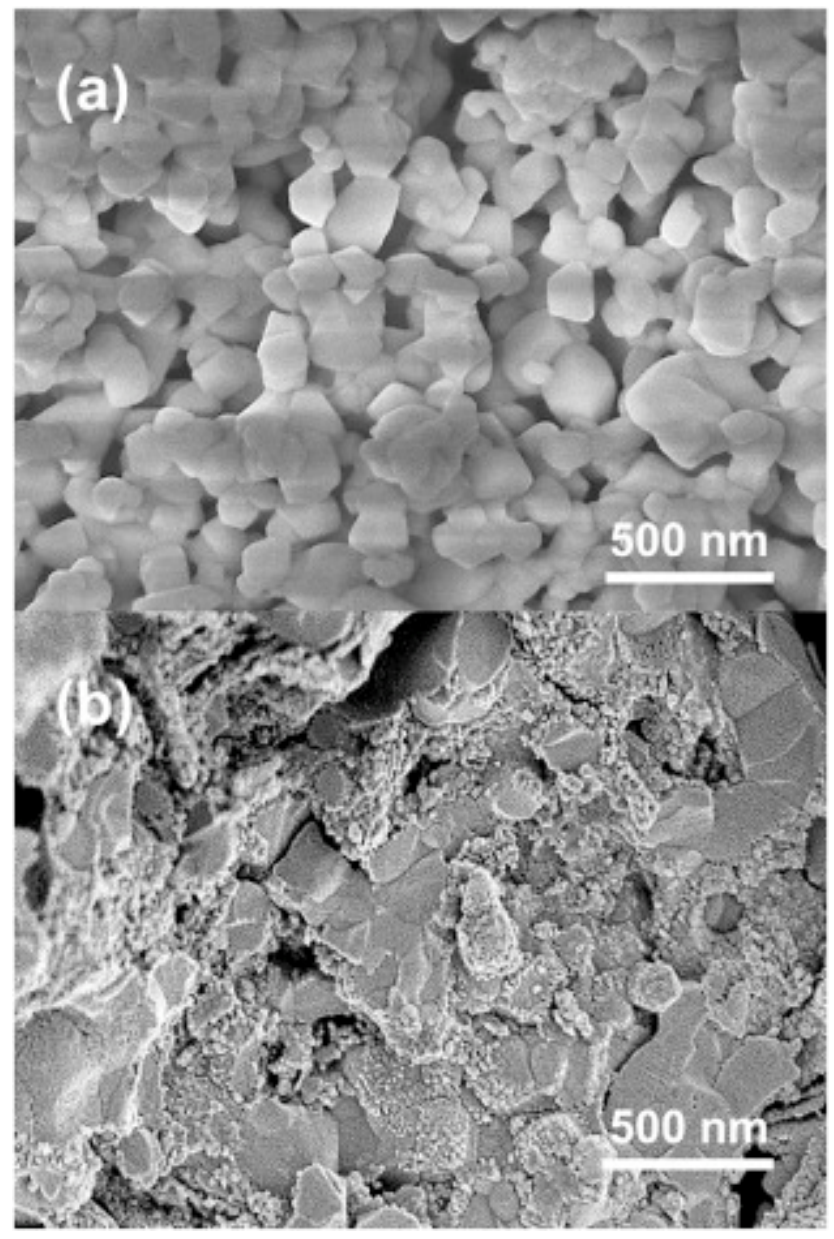

Fig. 3. SEM cross-section image of the GDC backbone prior to infiltration (a) and infiltrated with $30 \mathrm{wt}$. \% of $\mathrm{Pr}_{6} \mathrm{O}_{11}$, annealed at $600{ }^{\circ} \mathrm{C}$ for $2 \mathrm{~h}$ (b).

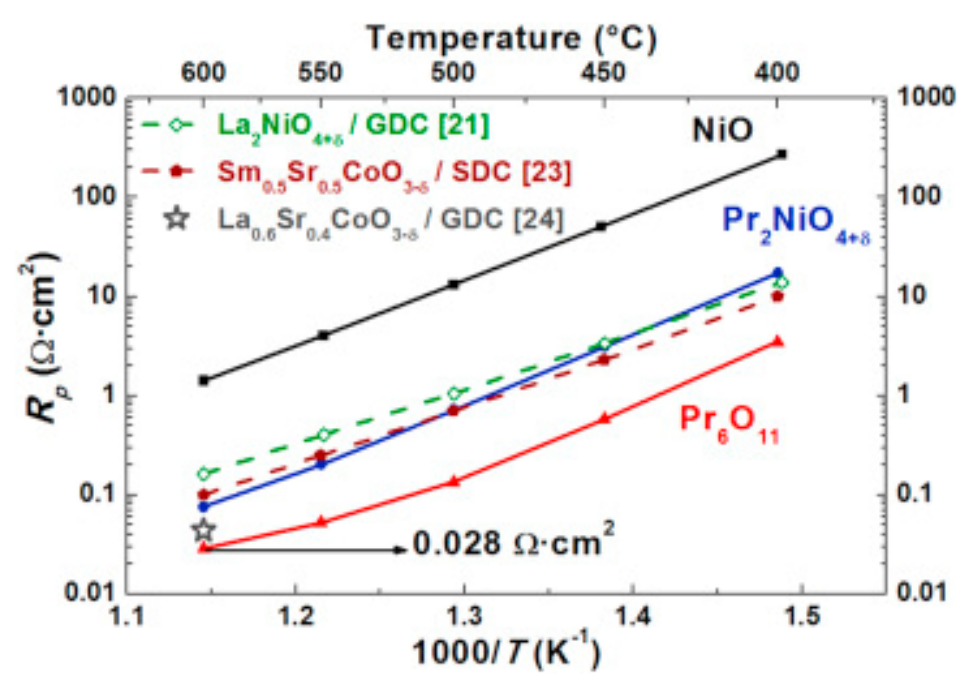

Fig. 4. Arrhenius plots of the polarization resistance of $G d$-doped ceria backbones infiltrated with $\mathrm{Pr}_{6} \mathrm{O}_{11}$, compared with results for electrodes infiltrated with $\mathrm{NiO}$ and $\mathrm{Pr}_{2} \mathrm{NiO}_{4+\delta}$, and reported

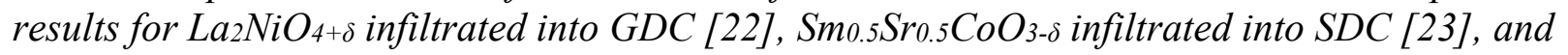
La $0.6 S_{0.4} \mathrm{CoO}_{3-\delta}$ infiltrated into GDC [24].

In addition, one can compare our results with similar infiltrated electrodes reported in the literature. An electrode of $\mathrm{La}_{2} \mathrm{NiO}_{4+\delta}$ infiltrated into GDC prepared in the same conditions led to a polarization resistance value of $0.15 \Omega \mathrm{cm}^{2}$ at $600{ }^{\circ} \mathrm{C}$ [22]. Nicholas and Barnett [23] reached a value of 
$0.10 \Omega \mathrm{cm}^{2}$ at $600{ }^{\circ} \mathrm{C}$ for $\mathrm{Sm}_{0.5} \mathrm{Sr}_{0.5} \mathrm{CoO}_{3-\delta}$ infiltrated into Sm-doped ceria backbones. Samson et al. [24] prepared $\mathrm{La}_{0.6} \mathrm{Sr}_{0.4} \mathrm{CoO}_{3-\delta}$ infiltrated into $\mathrm{GDC}$ electrodes and measured a polarization resistance of $0.044 \Omega \mathrm{cm}^{2}$ at $600{ }^{\circ} \mathrm{C}$.

The polarization resistance values measured here with $\mathrm{Pr}_{6} \mathrm{O}_{11}$ are lower than those of most wellknown cathode materials prepared with similar protocols (infiltration into ceria based backbones), which clearly demonstrates that $\mathrm{Pr}_{6} \mathrm{O}_{11}$ is a very promising material for SOFC cathodes.

For collecting the current, a $\mathrm{LaNi}_{0.6} \mathrm{Fe}_{0.4} \mathrm{O}_{3-\delta}$ layer is screen printed on the GDC backbone. As it is also infiltrated with $\operatorname{Pr}_{6} \mathrm{O}_{11}$, one can wonder about the role of this infiltrated LNF layer in the electrochemical response of the electrode. Thus, the next step was to determine the electrochemical contribution of the current collector. In this way, using the same process, backbones of LNF or of platinum (as reference for an electronic conductor) were both infiltrated with $\operatorname{Pr}_{6} \mathrm{O}_{11}$. The thermal variations of the polarization resistances of both infiltrated backbones (Fig. 5) are quite similar. At $600{ }^{\circ} \mathrm{C}$, the value of the polarization resistance is rather low, $R_{p}=0.072 \Omega \mathrm{cm}^{2}$, however, it is more than twice as high as that of the GDC backbone.

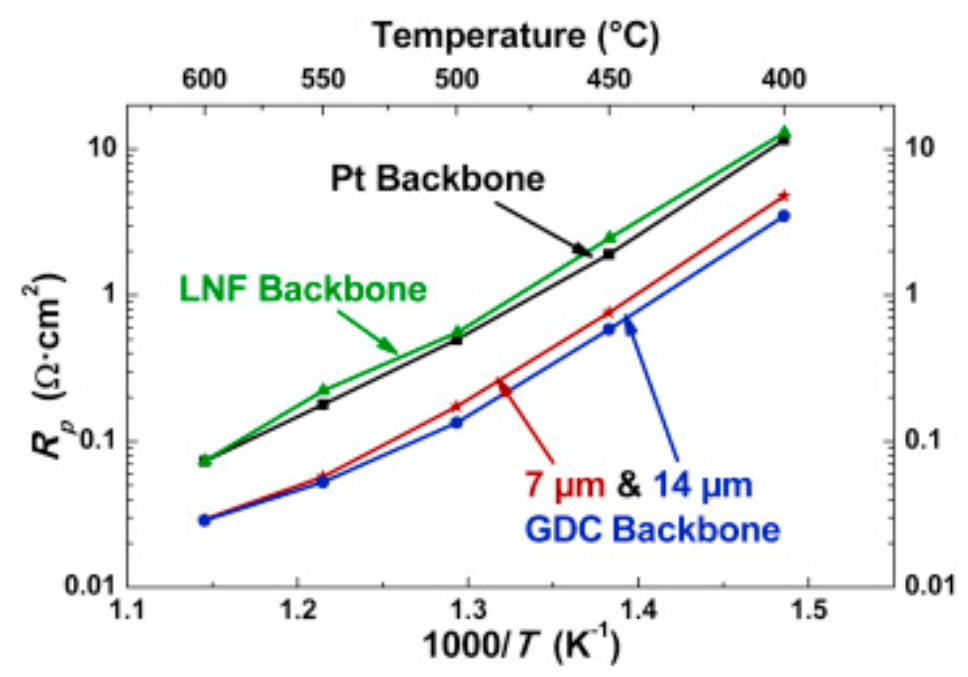

Fig. 5. Arrhenius plots of the polarization resistance of Pt, LNF and GDC backbones infiltrated with $\operatorname{Pr}_{6} \mathrm{O}_{11}$.

In addition, two GDC backbones with different thicknesses ( 7 and $14 \mu \mathrm{m})$ were infiltrated with $\mathrm{Pr}_{6} \mathrm{O}_{11}$. As shown in Fig. 5, they lead to exactly the same polarization resistance values. It proves that above a thickness of $7 \mu \mathrm{m}$ the polarization resistance does not depend on the thickness of the GDC backbone and that the electrochemical reaction occurs within a layer thickness equal or lower than $7 \mu \mathrm{m}$.

As a consequence of these results, one can conclude that the upper LNF layer strictly plays the role of a current collector. This is corroborated by the values of the diffusion length calculated from the fit of the impedance diagrams.

Fig. 6 shows the impedance diagrams measured at 400, 500, and $600{ }^{\circ} \mathrm{C}$ along with their fits. The oxygen electrode reaction (OER), can be fitted with a finite length Gerischer impedance proposed by Nielsen et al. [25] to model composite oxygen electrodes (equation (2)): 


$$
Z=R_{0} \frac{\operatorname{coth}\left(\left(L / \lambda_{0}\right) \sqrt{1+i \omega / k_{0}}\right)}{\sqrt{1+i \omega / k_{0}}}
$$

where $R_{0}$ is homogeneous to a resistance, $L$ the electrode thickness, the diffusion length that represents the thickness $\lambda_{0}$ of electrode where the reaction takes place and $k_{0}$ a rate constant related to the surface exchange reaction. The polarization resistance $R_{p}$ corresponds to the DC limit of this impedance, i.e. when $i_{\omega} \rightarrow 0$, which is:

$$
R_{p}=R_{0} \times \operatorname{coth}\left(L / \lambda_{0}\right)
$$

Compared to the typical Gerischer impedance, the finite length Gerischer takes into account the relationship between electrode thickness and diffusion length. If the thickness is much higher than the diffusion length the hyperbolic cotangent term reduces to 1 and the equation becomes similar to that of the typical Gerischer impedance.
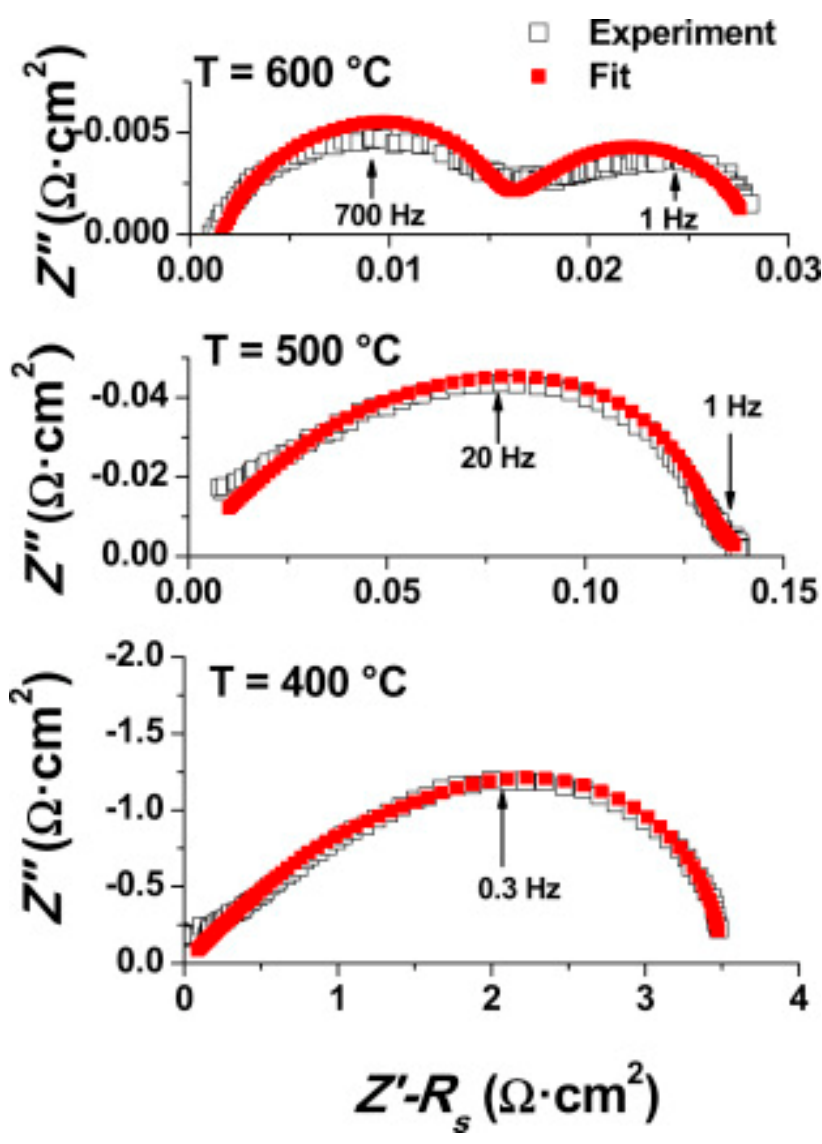

Fig. 6. Impedance diagrams recorded at 400, 500 and $600^{\circ} \mathrm{C}$, for an electrode of $\mathrm{Pr}_{6} \mathrm{O}_{11}$ infiltrated into GDC backbone with LNF collecting layer, annealed at $600{ }^{\circ} \mathrm{C}$ for $2 \mathrm{~h}$.

At $600{ }^{\circ} \mathrm{C}$ the diagram is fitted with an equivalent circuit constituted of a series resistance for the electrolyte (Rs), an induction element (L) to take the wires of the measurement set up into consideration, the finite length Gerischer impedance $(F L G)$ for the oxygen electrode reaction and a Warburg impedance (W) for the gas diffusion [25], [26], which yields the equivalent circuit: $R_{s}-L-$ $F L G-W$. At $500{ }^{\circ} \mathrm{C}$ the induction element is no longer needed as wires do not create inductive effect 
strong enough to affect the electrode response. At $400{ }^{\circ} \mathrm{C}$ only the series resistance and the finite length Gerischer remain, because the contribution related to gas diffusion is not detected, being too small compared to the contribution of the electrode reaction. The fit leads to the ratio between $L$ the electrode thickness and $\lambda_{0}$ the diffusion length, $\left(L / \lambda_{0}\right)$, equal to 1.5 for the measurement at $400{ }^{\circ} \mathrm{C}$, meaning that the electrode is thick enough $(14 \mu \mathrm{m})$ not to limit the electrode performance. This analysis has also been applied to the cell with a $7 \mu \mathrm{m}$ thick GDC backbone (not shown) and the $\left(L / \lambda_{0}\right)$ ratio was also higher than 1 over the whole temperature range, which further proves that the reaction only occurs within the GDC layer and does not extend to the LNF collecting layer. When the temperature increases the diffusion length decreases and the typical Gerischer impedance is sufficient to describe the contribution of the oxygen reduction reaction. The diagram recorded at $600{ }^{\circ} \mathrm{C}$ is not well defined as the associated resistances are very small, the corresponding fits being not as good as those obtained for diagrams recorded at lower temperatures.

\section{Electrochemical characterization of a single cell}

Finally, the praseodymium oxide infiltrated Gd-doped ceria cathode was prepared on a Ni-YSZ/YSZ half-cell and measured in a single cell configuration. Fig. 7a shows the voltage and power density of the single cell as a function of the current density. Measurements were performed at $600{ }^{\circ} \mathrm{C}$ under two different gas flow rates ( $\mathrm{H}_{2}$ : air): $60: 120 \mathrm{NmL} \cdot \mathrm{min}^{-1}$ and 125:250 NmL$\cdot \mathrm{min}^{-1}$. At low current densities, the voltage of the cell is almost independent of this flow rate, but it has a significant impact at higher current densities, where the cell voltage is mainly controlled by the concentration overpotential. It means that the concentration overpotential is in this case governed by the supply of reactants rather than the removal of products. The maximum power density is shifted by $65 \mathrm{~mW} \mathrm{~cm}^{-2}$ depending on the flow rates, with a maximum value for $\left(\mathrm{H}_{2}\right.$ : air): $125: 250 \mathrm{NmL} \cdot \mathrm{min}^{-1}$ reaching $825 \mathrm{~mW} \mathrm{~cm}^{-2}$. Achieving such a high power density at $600{ }^{\circ} \mathrm{C}$ is quite unusual and very promising for the $\operatorname{Pr}_{6} \mathrm{O}_{11}$ infiltrated electrode. Indeed, this result can be compared with the power density of the commercial cell using a lanthanum cobaltite cathode or with that of $\mathrm{La}_{2} \mathrm{NiO}_{4+\delta}$ infiltrated into Gddoped ceria cathode [27], both prepared using the same commercial Ni-YSZ/YSZ half-cell. Maximum power densities of 400 and $250 \mathrm{~mW} \mathrm{~cm}^{-2}$, respectively, are measured. They are 2 or 3 times lower than our single cell and only dependent on the infiltrated phase of the cathode, which clearly points out that $\operatorname{Pr}_{6} \mathrm{O}_{11}$ is a very efficient catalyst for the oxygen reduction reaction.

Then, this single cell was aged at $600{ }^{\circ} \mathrm{C}$. The current density was set at $0.5 \mathrm{~A} \mathrm{~cm}^{-2}$ with flow rates of reactants at $\left(\mathrm{H}_{2}\right.$ : air): $60: 120 \mathrm{NmL} \mathrm{min}^{-1}$ in $\mathrm{H}_{2}$ and air. Fig. $7 \mathrm{~b}$ shows the variation of the cell voltage versus time. The cell potential remains fairly stable at around $0.82 \mathrm{~V}$ during the whole experiment $(840 \mathrm{~h})$, the extrapolated degradation rate over $1000 \mathrm{~h}$ being lower than $1 \%$, which proves that the infiltrated electrode keeps its high electrocatalytic activity even after long time operation. 


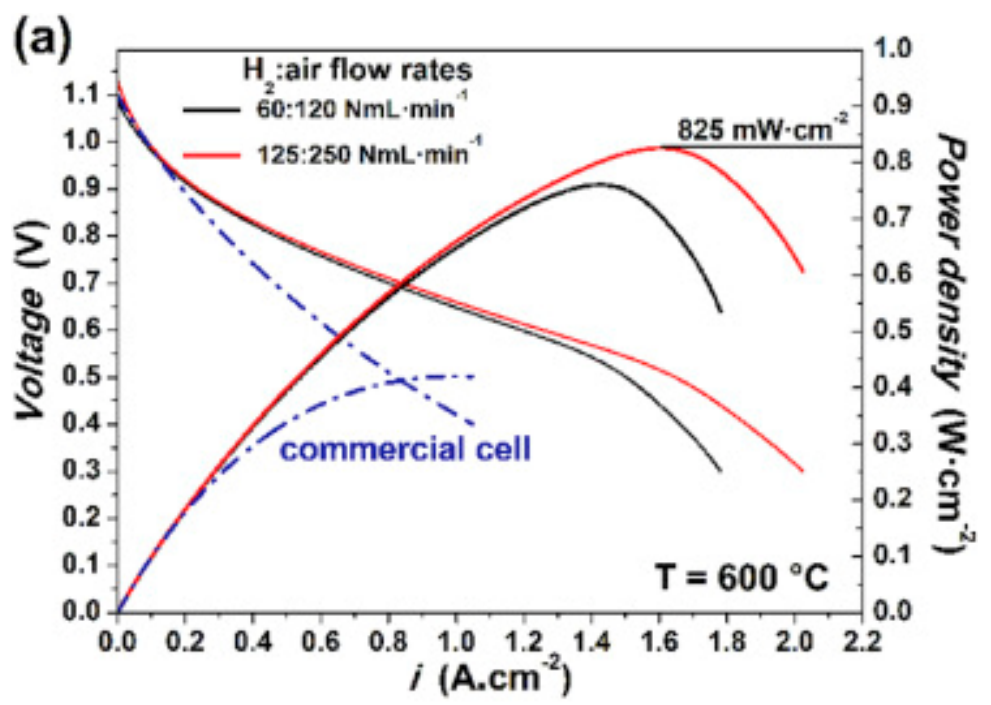

(b)

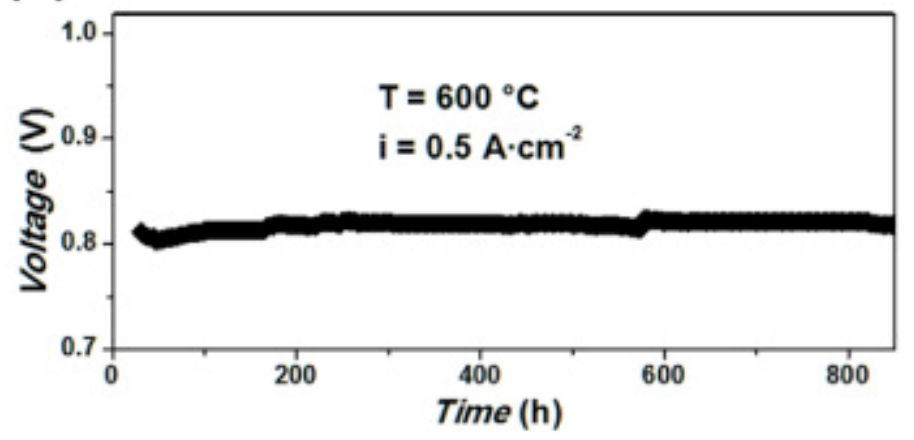

Fig. 7. (a) $i-V$ and power density curves of a single cell with $\mathrm{Pr}_{6} \mathrm{O}_{11}$ infiltrated cathode, measured at $600{ }^{\circ} \mathrm{C}$, for two different gas flow rates; (b) Cell voltage measured at $600{ }^{\circ} \mathrm{C}$ and $0.5 \mathrm{~A} \mathrm{~cm}^{-2}$ for $840 \mathrm{~h}$. The characteristics of a commercial cell from Elcogen have been measured in a (H2:air)

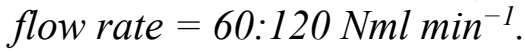

Such a result is encouraging for infiltrated electrodes that are often believed, as the catalyst is nanoscaled, to be subject to Oswald ripening issues that decrease the specific surface area [28]. These phenomena are often observed when the cell is aged at higher temperatures, and $600{ }^{\circ} \mathrm{C} \mathrm{might} \mathrm{be} \mathrm{low}$ enough to prevent it. One can point out that, this catalyst being a simple oxide; it cannot be subject to decomposition as it can occur in perovskites or RP phases [5], [6]. In addition, $\operatorname{Pr}_{6} \mathrm{O}_{11}$ electrodes do not contain $\mathrm{Sr}$ cations, and all concerns related to the presence of $\mathrm{Sr}$ such as reactivity with $\mathrm{Cr}$ from interconnects that forms insulating $\mathrm{SrCrO}_{4}$ [3], [29], [30], or surface segregation [31], [32] that affects the cell durability, are avoided, which constitutes a strong advantage for the cell durability.

\section{Conclusion}

Praseodymium oxide, $\operatorname{Pr}_{6} \mathrm{O}_{11}$, was investigated as a potential electrocatalyst for the oxygen reduction reaction for fuel cell application. Its electrical conductivity is sufficient with regard to the prerequisite of a SOFC cathode. The oxygen diffusion and the surface exchange coefficients have been measured at $600{ }^{\circ} \mathrm{C}$ and are quite similar to those of $\operatorname{Pr}_{2} \mathrm{NiO}_{4+\delta}$, known for its very high $D^{*}$ and $k^{*}$ values.

The composite electrodes were prepared by infiltration of praseodymium nitrate into a Gd-doped ceria backbone and fired at $600{ }^{\circ} \mathrm{C}$. The impedance spectroscopy measurements on symmetrical cells showed values of polarization resistance as low as $0.028 \Omega \mathrm{cm}^{2}$ at $600{ }^{\circ} \mathrm{C}$, which is among the lowest $R_{p}$ ever reported at this temperature. Such an electrode was then prepared on Ni-YSZ/YSZ 
commercial half-cell to make a single cell. A remarkable maximum power density of $0.825 \mathrm{~W} \mathrm{~cm}^{-2}$ was measured at $600{ }^{\circ} \mathrm{C}$. At a current load of $0.5 \mathrm{~A} \mathrm{~cm}^{-2}$, the cell voltage remained stable for $840 \mathrm{~h}$, with a degradation rate lower than $1 \%$ per $1000 \mathrm{~h}$.

Up to now, $\operatorname{Pr}_{6} \mathrm{O}_{11}$ has only been considered as an improvement of other electrode materials such as

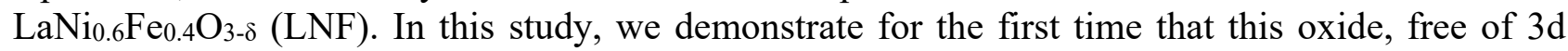
cations, can be used alone as an excellent electrocatalyst for the oxygen reduction reaction in SOFC. As the active material is a simple oxide, there are no decomposition issues that could affect the cell performance, and as it is Sr-free, all issues related to $\mathrm{Sr}$ migration and reactivity with other cell components are avoided as well.

To conclude, $\mathrm{Pr}_{6} \mathrm{O}_{11}$ is a very promising electrode material for SOFC applications thanks to its high electrocatalytic activity and stability.

\section{Acknowledgments}

The authors gratefully acknowledge Bernhard Zeimetz for including the finite length Gerischer impedance into the development of the CANELEIS software, and Teresa Hungria from INSA Toulouse for performing the SIMS measurements.

\section{References}

[1] S. Adler. Factors governing oxygen reduction in solid oxide fuel cell cathodes. Chem Rev, 104 (2004), pp. 4791-4843.

[2] J.-C. Grenier, J.-M. Bassat, F. Mauvy, J.A. Kilner, S.J. Skinner, S.J.C. Irvine, P.P. Edwards (Eds.), Functional materials for sustainable energy applications, Woodhead Publishing (2012), pp. 402-444.

[3] Y. Chen, W. Zhou, D. Ding, M. Liu, F. Ciucci, M. Tade, et al.Advances in cathode materials for solid oxide fuel cells: complex oxides without alkaline earth metal elements. Adv Energy Mater, 5 (18) (2015), p. 1500537.

[4] E. Boehm, J.-M. Bassat, P. Dordor, F. Mauvy, J.-C. Grenier, P. StevensOxygen diffusion and transport properties in non-stoichiometric $\mathbf{L n}_{2-\mathbf{x}} \mathbf{N i O}_{4+\delta}$ oxides. Solid State Ionics, 176 (2005), pp. 2717-2725.

[5] A. Kovalevsky, V. Kharton, A. Yaremchenko, Y. Pivak, E. Naumovich, J. Frade. Stability and oxygen transport properties of $\operatorname{Pr}_{2} \mathbf{N i O}_{4+\delta}$ ceramics. J Eur Ceram Soc, 27 (13-15) (2007), pp. 4269-4272.

[6] V. Vibhu, J.-M. Bassat, A. Flura, C. Nicollet, J.-C. Grenier, A. Rougier. Influence of La/Pr ratio on the ageing properties of $\mathrm{La}_{2-x} \mathrm{Pr}_{\mathbf{x}} \mathrm{NiO}_{4+\delta}$ as cathodes in IT-SOFCs. ECS Trans, 68 (2015), pp. 825-835.

[7] C. Nicollet, A. Flura, V. Vibhu, S. Fourcade, A. Rougier, J. Bassat, et al.Preparation and characterization of $\operatorname{Pr}_{2} \mathrm{NiO}_{4+\delta}$ infiltrated into Gd-doped ceria for SOFC cathode. J Solid State Electrochem (2016), 10.1007/s10008-016-3211-X.

[8] R. Chiba, H. Aono, K. KatoAn SOFC cathode infiltrated with $\operatorname{Pr}_{6} \mathbf{O}_{11}$. ECS Trans, 57 (2013), pp. 1831-1840.

[9] H. Taguchi, R. Chiba, T. Komatsu, H. Orui, K. Watanabe, K. HayashiLNF SOFC cathodes with active layer using $\operatorname{Pr}_{6} \mathrm{O}_{11}$ or Pr-doped $\mathbf{C e O}_{2}$. J Power Sources, 241 (2013), pp. 768-775. 
[10] X. Ding, W. Zhu, G. Hua, J. Li, Z. Wu. Enhanced oxygen reduction activity on surfacedecorated perovskite $\mathrm{La}_{0.6} \mathrm{Ni}_{0.4} \mathrm{FeO}_{3}$ cathode for solid oxide fuel cells. Electrochim Acta, 163 (2015), pp. 204-212.

[11] L. Navarrete, C. Solis, J.M. Serra. Boosting the oxygen reduction reaction mechanisms in IT-SOFC cathodes by catalytic functionalization. J Mater Chem A, 3 (2015), pp. 16440-16444.

[12] B.G. Hyde, E.E. Garver, U.E. Kuntz, L. Eyring. Kinetic studies on reactions of praseodymium oxides in an oxygen atmosphere: $\mathrm{PrO}_{1.83}+\mathbf{O}_{\mathbf{2}} \rightleftarrows \mathrm{PrO}_{2}$. J Phys Chem, 69 (5) (1965), pp. 1667-1675.

[13] V. Thangadurai, R. Huggins, W. WeppnerMixed ionic-electronic conductivity in phases in the praseodymium oxide system. J Solid State Electrochem, 5 (2001), pp. 531-537.

[14] M.B. Bellakki, C. Shivakumara, T. Baidya, A. Prakash, N. Vasanthacharya, M. H egde. Synthesis, structure and oxygen-storage capacity of $\operatorname{Pr1-x} Z_{r_{x}} O_{2-\delta}$ and $\operatorname{Pr}_{1-x-y} P_{y} Z_{r_{x}} O_{2-\delta}$. Mater Res Bull, 43 (10) (2008), pp. 2658-2667.

[15] J. Vohs, R. GorteHigh-performance SOFC cathodes prepared by infiltration. Adv Mater, 21 (2009), pp. 943-956.

[16] D. Ding, X. Li, S. Lai, K. Gerdes, M. Liu. Enhancing SOFC cathode performance by surface modification through infiltration. Energy Environ Sci, 7 (2014), pp. 552-575.

[17] S. Jiang. A review of wet impregnation - an alternative method for the fabrication of high performance and nano-structured electrodes of solid oxide fuel cells. Mater Sci Eng A, 418 (12) (2006), pp. 199-210.

[18] G. Rao, S. Ramdas, P. Mehrotra, C. Rao. Electrical transport in rare-earth oxides. J Solid State Chem, 2 (3) (1970), pp. 377-384.

[19] R. De Souza, J. Kilner, J. Walker. SIMS study of oxygen tracer diffusion and surface exchange in $\mathrm{La}_{0.8} \mathrm{Sr}_{0.2} \mathrm{MnO}_{3+\delta}$. Mater Lett, 43 (1) (2000), pp. 43-52.

[20] C. Ferchaud, J.-C. Grenier, Y. Zhang-Steenwinkel, M. Van Tuel, F. Van Berkel, J.-M. Bassat. High performance praseodymium nickelate oxide cathode for low temperature solid oxide fuel cell. J Power Sources, 196 (2011), pp. 1872-1879.

[21] J.G. Railsback, Z. Gao, S.A. BarnettOxygen electrode characteristics of $\mathbf{P r}_{2} \mathbf{N i O}_{4+\delta}-$

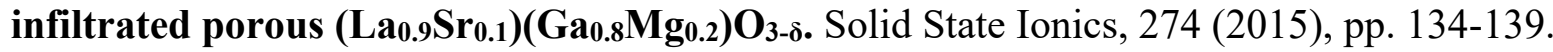

[22] C. Nicollet, A. Flura, V. Vibhu, A. Rougier, J. Bassat, J. Grenier. La $\mathbf{a}_{2} \mathbf{N i O}_{4+\delta}$ infiltrated into Gd-Doped Ceria SOFC cathodes: electrochemical performance and impedance modelling. J Power Sources, 294 (2015), pp. 473-482.

[23] J. Nicholas, S. BarnettMeasurements and modeling of $\mathrm{Sm}_{0.5} \mathrm{Sr}_{0.5} \mathrm{CoO}_{3-\delta}-\mathrm{Ce}_{0.9} \mathbf{G d}_{0.1} \mathrm{O}_{1.95}$ SOFC cathodes produced using infiltrate solution additives. J Electrochem Soc, 157 (2010), pp. B536-B541.

[24] A. Samson, M. Søgaard, R. Knibbe, N. Bonanos. High performance cathodes for solid oxide fuel cells prepared by infiltration of $\mathrm{La}_{0.6} \mathrm{Sr}_{0.4} \mathrm{CoO}_{3-\delta}$ into Gd-doped ceria. J Electrochem Soc, 158 (2011), pp. B650-B659.

[25] J. Nielsen, T. Jacobsen, M. Wandel. Impedance of porous IT-SOFC LSCF: CGO composite cathodes. Electrochim Acta, 56 (2011), pp. 7963-7974.

[26] A. Flura, C. Nicollet, S. Fourcade, V. Vibhu, A. Rougier, J.-M. Bassat, et al. Identification and modelling of the oxygen gas diffusion impedance in SOFC porous electrodes: application to $\mathrm{Pr}_{2} \mathrm{NiO}_{4+\boldsymbol{\delta}}$. Electrochim Acta, 174 (2015), pp. 1030-1040. 
[27] C. Nicollet, A. Flura, V. Vibhu, A. Rougier, J. Bassat, J. Grenier. Lanthanum nickelate infiltration into porous Gd-doped ceria as cathode for solid oxide fuel cells. ECS Trans, 68 (2015), pp. 837-845.

[28] T. Sholklapper, C. Jacobson, S. Visco, L. Dejonghe. Synthesis of dispersed and contiguous nanoparticles in solid oxide fuel cell electrodes. Fuel Cells, 8 (2008), pp. 303-312.

[29] S. Jiang, X. Chen. Chromium deposition and poisoning of cathodes of solid oxide fuel cells - a review. Int J Hydrogen Energy, 39 (1) (2014), pp. 505-531.

[30] S. Jiang, S. Zhang, Y. ZhenDeposition of Cr species at ( $\mathrm{La}, \mathrm{Sr})(\mathrm{Co}, \mathrm{Fe}) \mathrm{O}_{3}$ cathodes of solid oxide fuel cells. J Electrochem Soc, 153 (1) (2006), pp. A127-A134.

[31] D. Oh, D. Gostovic, E. Wachsman. Mechanism of $\mathrm{La}_{0.6} \mathrm{Sr}_{0.4} \mathrm{Co}_{0.2} \mathrm{Fe}_{0.8} \mathrm{O}_{3}$ cathode degradation. J Mater Res, 27 (15) (2012), pp. 1992-1999.

[32] S. Simner, M. Anderson, M. Engelhard, J. Stevenson. Degradation mechanisms of La-Sr-

Co-Fe-O 3 SOFC cathodes. Electrochem Solid-State Lett, 9 (10) (2006), pp. A478-A481. 